\title{
INCOME INEQUALITY IN LOW-INCOME COUNTRIES: REASONS AND FUNDAMENTAL SOLUTIONS
}

\author{
Sanzharbek Mavlianov \\ MSc, Faculty of Economics and Social Sciences, Szent István University \\ Email: s.mavlianov@gmail.com
}

\begin{abstract}
This paper presents the problem of unequal distribution of income in low-income countries according to classification of World Bank - through introducing and heavily reviewing theoretical and empirical studies. Exploring the reasons of income inequality in those countries one must assert that there are complex interactions between past and present and between the diverse political, economic and social processes, cultural values, national and external factors and institutions. Keeping in mind all these aspects of historical interaction, many scholars, researchers and policy makers suggest apparent solutions for concerning issue that are, briefly, taxing the poor less, taxing the rich more, and providing more social services for the poor, working, and middle social classes.
\end{abstract}

Keywords: Inequality, GINI, Kuznets curve, Lorenz curve, Poverty JEL classification: $\mathrm{O} 15$

\section{Introduction}

"Any city, however small, is in fact divided into two, one the city of the poor, the other of the rich; these are at war with one another." Plato, Greek philosopher (427-347 B.C.)

Today as all we know the income inequality problem is one of the most crucial global problems all around the world. However, it is most crucial in less developed countries. To illustrate the income inequality between rich and poor countries, consider these facts: about 1.75 billion people live in multi-dimensional poverty, meaning extreme deprivation in education, health, and standard of living.(World Bank, 2010) Today almost nobody work on solving income inequality issues in less developed, so called low income countries, particularly in Kyrgyzstan. Presented paper raises the issue and makes an analysis of this problem in the country. The goal of the research is to reveal the role of income inequality in country's economy, determine the reasons of income inequality in less developed countries and their possible solutions towards development.

\section{General overview on income inequality theories}

An evidence from a broad panel of recent academic studies shows that there is a nonlinear relation between income inequality and the rate of growth and investment. Very high inequality slows growth; moderate inequality encourages growth. Studies differ on the effect of very low inequality. Robert J. Barro, Harvard University found in his study "Inequality and Growth in a Panel of Countries" that higher inequality tends to retard growth in poor countries and encourage growth in well-developed regions. In their study for the World Institute for Development Economics Research, Giovanni Andrea Cornia and Julius Court (2001) reach slightly different conclusions. The authors therefore recommend to pursue moderation also as to the distribution of wealth and particularly to avoid the extremes. Both very high egalitarianism and very high inequality cause slow growth. 
Considering the inequalities in economically well developed countries, public policy should target an 'efficient inequality range'. The authors claim that such efficiency range roughly lies between the values of the Gini coefficients of 25 (the inequality value of a typical Northern European country) and 40 (that of countries such as the USA, France, Germany and the UK).

Another researcher, W.Kitterer, has shown that in perfect markets inequality does not influence growth. The precise shape of the inequality-growth curve obviously varies across countries depending upon their resource endowment, history, remaining levels of absolute poverty and available stock of social programs, as well as on the distribution of physical and human capital.

There are also some important and main theories that are called the fundamentals of income inequality in the economic growth and development.

Kuznets curve. Kuznets curve is the graphical representation of Simon Kuznets' hypothesis that as a country develops, there is a natural cycle of economic inequality driven by market forces which at first increases inequality, and then decreases it after a certain average income is attained. Kuznets' belief was that an inequality would follow an inverted "U" shape as it rises and then falls again with the increase of income per capita.(Flemming, et al. 2000)

Lorenz Curve. In economics, the Lorenz curve, Figure 1, is a graphical representation of the cumulative distribution function of the empirical probability distribution of wealth. It is often used to represent income distribution, where it shows for the bottom $\mathrm{x} \%$ of households, what percentage $\mathrm{y} \%$ of the total income they have. Every point on the Lorenz curve represents a statement like "the bottom $20 \%$ of all households have $10 \%$ of the total income." (Dieninger, Squire, 1999)

Among the most common metrics used to measure inequality are the Gini index (or Gini coefficient), the Theil index, and the Hoover index.

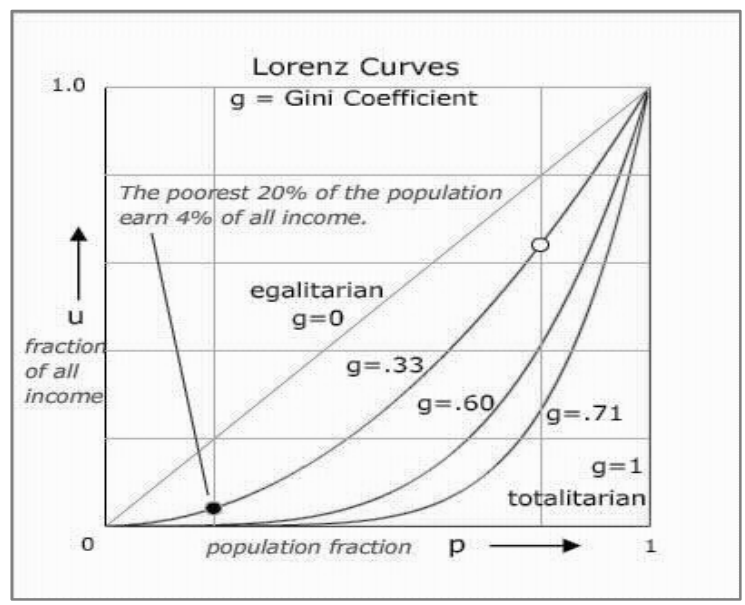

Figure 1. Lorenz Curve

Source: Economic curves, E-ducation.net/07 


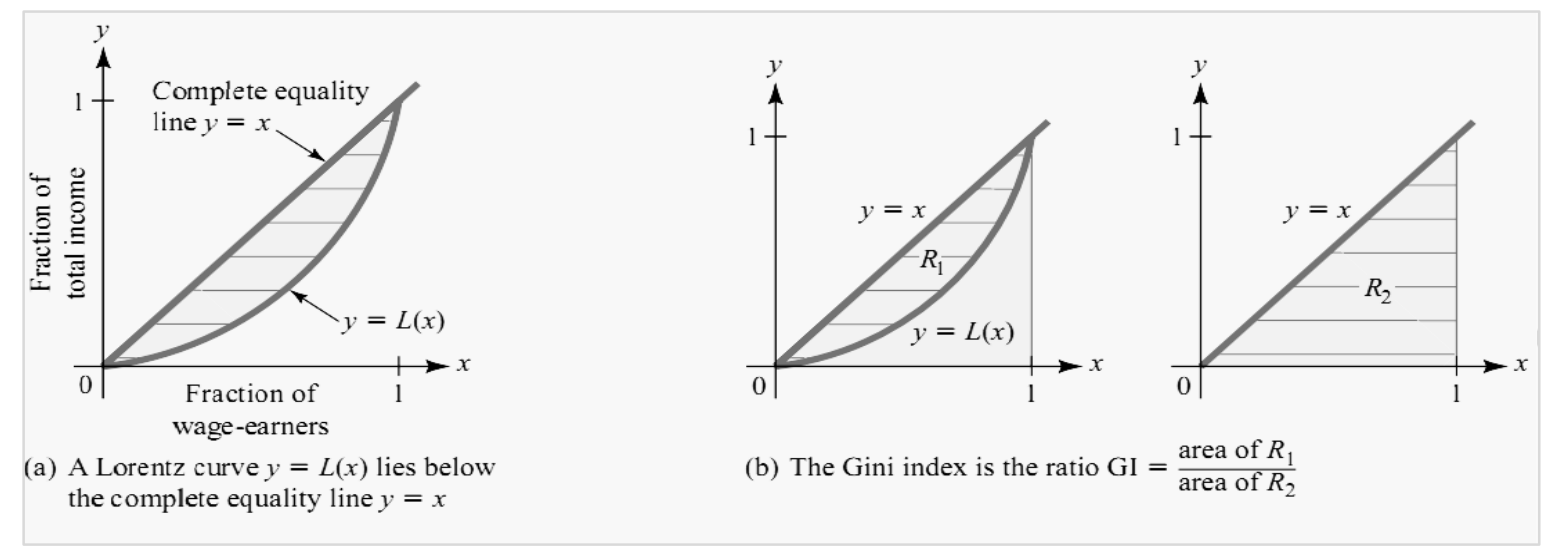

Figure 2. Calculus of GINI Index

Source: Laurence D. Hoffmann; Calculus For Business, Economics, and the Social and Life

\section{Reasons of income inequality in low-income countries}

There are many reasons for income or economic inequality within societies. "The single most important driver has been greater inequality in wages and salaries (OECD 2011-12-05)". These causes are often inter-related. Acknowledged factors that impact income inequality include:

1) Labor markets and greater inequality in wages and salaries.

2) Education and computerization/growing technology

3) Financial reasons: Inflation

Table 1. GINI Index of Low income countries

\begin{tabular}{|l|c|l|c|l|c|}
\hline Country & GINI & Country & GINI & Country & GINI \\
\hline Afghanistan & 27.82 & Kyrgyz Republic & 33.38 & Rwanda & 50.82 \\
\hline Bangladesh & 32.12 & Liberia & 38.16 & Sierra Leone & 35.35 \\
\hline Burkina Faso & 39.79 & Madagascar & 44.11 & South Sudan & 45.53 \\
\hline Central A.R. & 56.3 & Malawi & 43.91 & Tajikistan & 30.83 \\
\hline Ethiopia & 33.6 & Mali & 33.02 & Tanzania & 37.58 \\
\hline Guinea & 39.35 & Mozambique & 45.66 & Togo & 39.29 \\
\hline Kenya & 47.68 & Nepal & 32.82 & Uganda & 44.3 \\
\hline
\end{tabular}

Source: World Bank Data, 2008-2012

\section{Factors influencing income inequality}

1. Economic growth and the overall development level of a country.

2. Macroeconomic factors are inflation and unemployment, the size of government's expenditure, external debt and foreign reserves, changes in the exchange rate, and other factors.

3. Demographic factors include processes of demographic development, including the age structure of population (share of economically active population), the growth and density of population; urbanization, level of human capital, including the level of education and health condition of population.

4. Political factors include privatization and the share of the private sector, level of taxes and the share of the public sector, openness of a country, especially trade openness and freedom of labor movement; social policy and other decisions of economic policy. 
5. Historical, cultural and natural factors, which among others include distribution of land ownership, people's attitude to inequality, extent of shadow economy, which are all formed in the course of long history.

6. Poverty and inequality.(Kaasa, 2003)

\section{Fundamental ways of solving the problems of income inequality}

According to empirical studies of Clark on income inequality, many factors constrain income inequality - they may be divided into two classes:

1) Government sponsored, and

2) Market driven

The relative merits and effectiveness of each approach is a subject of debate. Typical government initiatives to reduce economic inequality include:

- Public education: increasing the supply of skilled labor and reducing income inequality due to education differentials.

- Progressive taxation: the rich are taxed proportionally more than the poor, reducing the amount of income inequality in society.

- Minimum wage legislation: raising the income of the poorest workers.

- Nationalization or subsidization of products: providing goods and services that everyone needs cheaply or freely (such as food, healthcare, and housing), governments can effectively raise the purchasing power of the poorer members of society.

Market forces outside of government intervention that can reduce economic inequality include:

- Propensity to spend: with rising wealth \& income, a person must spend more. In an extreme example, if one person owned everything, they would immediately need to hire people to maintain their properties, thus reducing the wealth concentration.

- Unionization: although not a market force, per se, labor organizations may reduce inequality by negotiating standard pay rates (though probably increasing unemployment). As union power has declined, and performance related pay has become more widespread, economic inequality has mirrored productive inequality.

Another way we can decrease inequality is to increase social services such as the following:

- increase food stamps for poor people; raise the minimum wage; increase social security for people in the poor, working, and middle classes; increase unemployment compensation; create more college grants and loans for people in the poor, working, and middle classes; create more child care subsidies for lower income single parents who are working at (near) minimum wage jobs so that they can work and survive at these kinds of jobs; create more housing subsidies for poor and lower income families; expand programs for poorer and lower income people; and increase funding for public schools located in poor and lower income neighborhoods so that children from these neighborhoods get the same quality public education as do children in middle-class and upper middle-class neighborhoods. 


\section{Conclusion}

Changes in the distribution of income and wealth associated with globalization, the restoration of the market system, the growing income gap in the less developed countries, and the rise of the nouveau riche have brought issues of inequality into national politics. The political implications are country specific as the countries are extremely diverse in terms of size, level of development, historical background, and social and political structure and are related to the characteristics of the regimes. There are complex interactions between past and present and between the diverse political, economic and social processes, cultural values, national and external factors and institutions. Keeping all these aspects of historical interaction, many scholars, researchers and policy makers provide apparent and fundamental solutions for income inequality, that are taxing the poor less, taxing the rich more, and providing more social services for the poor, working, and middle social classes.

\section{Bibliography}

1. Amiel, Y. Frank, A 1998. Thinking about Inequality: Personal Judgment and Income Distributions, London School of Economics, Ruppin Institute, Israel http://dx.doi.org/10.1017/CBO9780511492266.007

2. Atkinson, A. 1970. "On the Measurement of Inequality". Journal of Economic Theory 2: 244-63. Retrieved 19 March 2013.

3. Atkinson, A.Bourguignon, F. ed. 2000. Handbook of Income Distribution, v. 1 Elsevier B.V. http://dx.doi.org/10.1016/S1574-0056(00)80003-2

4. Berg G., Ostry. D. 2011. Inequality and Unsustainable Growth: Two Sides of the Same \begin{tabular}{l|llll|ll} 
Coin? & IMF & STAFF & DISCUSSION
\end{tabular} http://dx.doi.org/10.5089/9781463926564.006

5. Clark J. 2008. "The impact of economic growth, tax policy and economic freedom on income inequality - Conclusions", The Journal of Private Enterprise 24(1), 23-31

6. Deininger, K. Squire, L. 1998. Journal of Development Economics 57 (2), "New Ways of Looking at Old Issues: Inequality and Growth". 259-287. http://dx.doi.org/10.1016/S0304-3878(98)00099-6

7. Flemming, J. 1999. "Income Distribution, Economic Systems and Transition", Oxford; Wadham College, p. 40; May.

8. Kaasa, A. 2003. "Factors influencing income inequality in transition economies", Journal of Transforming Economies and Societies, p.11-15

9. Laurence D. 2007. Calculus For Business, Economics, and the Social and Life Sciences, p. 421

10. Musaeva D.A. 2011. Formation strategy for development of agro processing complex in KR under globalization and underlying challenges; Alatoo Academic Studies, Bishkek, Kyrgyzstan, p 35.

11. Novotny, J. 2007. "On the measurement of regional inequality", The Annals of Regional Science, Volume 41, Issue 3, pp 563-580

12. World Institute for Development Economics Research Database, World Income Inequality Database V2.0c May 2008 